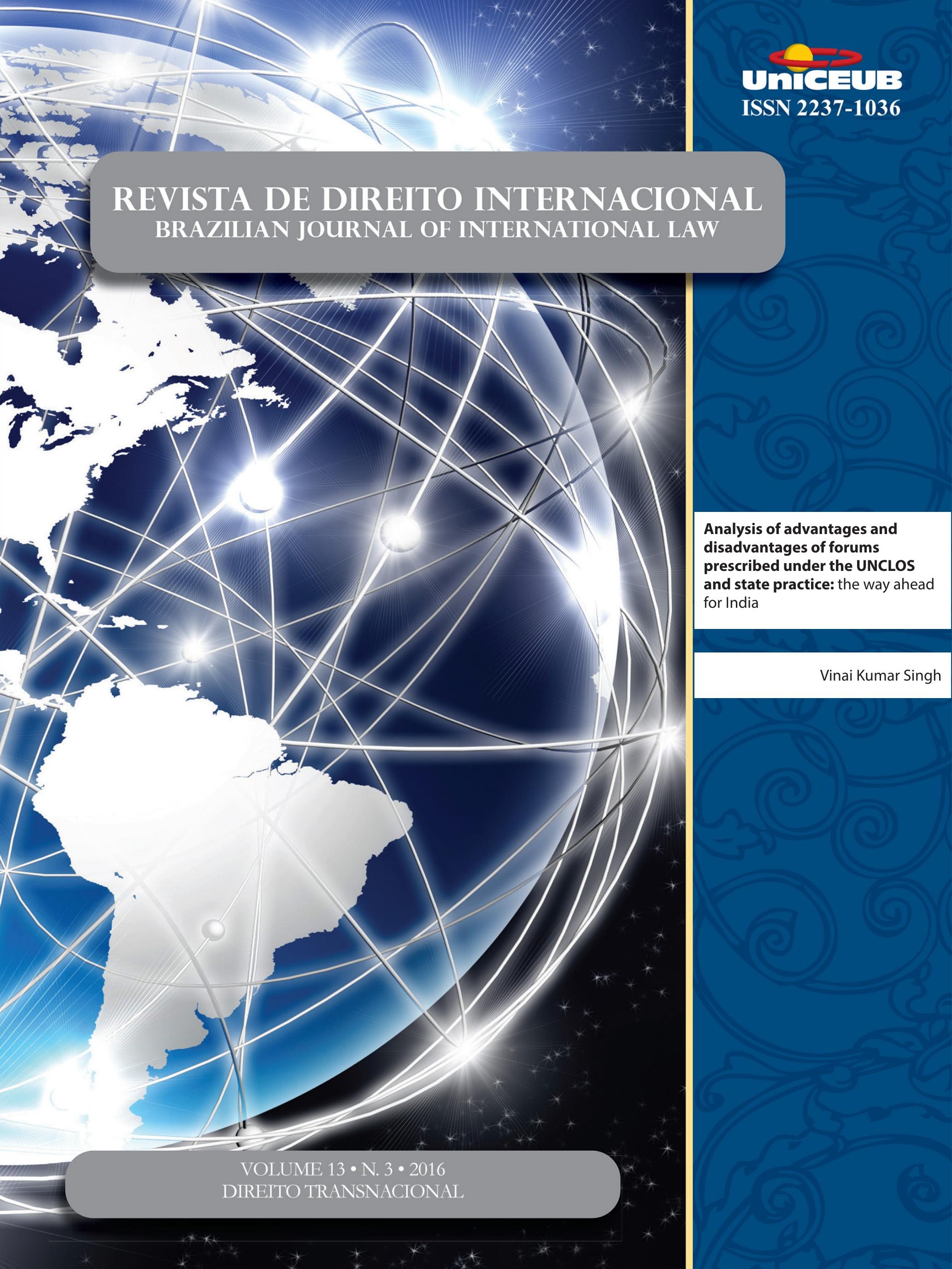


Crônicas da ATUALIdAde do direito internacional .................................................. 2

I. Dossiê Temático: Direito Transnacional .........................................................15

EDITORIAL: O Direito Transnacional - Circulação de normas e relações jurídicas transnacionais .......16 Priscila Pereira de Andrade

A emergênCia do direito transnacional ambiental .............................................18 Priscila Pereira de Andrade

Desafíos y RESPUESTAS TRANSNACIONALES FRENTE A LOS CRÍMENES AMBIENTALES ...............30 Rosmerlin Estupiñan-Silva

DiREITO TRANSNACIONAL E MUdANÇAS CLIMÁTICAS .50 Géraud de Lassus Saint-Geniès

Especies en movimiento: la Convención sobre el Comercio Internacional de Especies Amenazadas de Fauna y Flora Silvestres como espacio de “Encuentro” de discursos, ACTORES Y ESTRATEGIAS EN EL DERECHO AMBIENTAL TRASNACIONAL

María Valeria Berros e Dabel Leandro Franco

El carácter transnacional del Sistema comunitario de ECogestion « Eco-ManageMENT AND Audit SCHEME » (EMAS) DENTRo de LA UE y MÁs ALlÁ DE SUS Fronteras ......72 Adélie Pomade

O CONCEITO DE CONDUTA EMPRESARIAL RESPONSÁVEL À LUZ DOS ORDENAMENTOS JURÍDICOS BRASILEIRO, INTERNACIONAL E TRANSNACIONAL

Gabriel Webber Ziero

ARBITRAGEM NO DIREITO TRIBUTÁRIO INTERNACIONAL E NO DIREITO INTERNACIONAL DOS INVESTIMENTOS: UMA MANIFESTAÇÃO DO DIREITO TRANSNACIONAL

Vivian Daniele Rocha Gabriel 
O DIREITO TRIBUTÁRIO SOB UMA PERSPECTIVA TRANSNACIONAL

Franciele de Simas Estrela Borges

As Características do Direito Transnacional como Metodologia: Análise sob o enfoQue dos Aspectos Processuais da Arbitragem 126

Flávia Foz Mange

O DIREITO TRANSNACIONAL (“GLOBAL LAW") E A CRISE DE PARADIGMA DO ESTADO-CENTRISMO: É POSSÍVEL CONCEBER UMA ORDEM JURÍDICA TRANSNACIONAL? ...................................... 146

Luiza Nogueira Barbosa e Valesca Raizer Borges Moschen

TransPorte AÉREO E DIREITO TRANSNACIONAL: DA CONVERGÊNCIA À UNIFORMIDADE 160 Mickael R. Viglino

Outros Artigos. 175

O Fundo Monetário Internacional e a proteção dos direitos humanos: uma análise DO PROGRAMA DE CRESCIMENTO E REDUÇÃO DA POBREZA NO HAITI 177

Pablo Henrique Hubner de Lanna Costa e Carlos Alberto Simões de Tomaz

Um estranho no ninho? Padrões privados no Acordo de Barreiras Técnicas ao CoMÉRCIO DA OMC 192

Michelle Ratton Sanchez Badin e Marina Yoshimi Takitani

Os benefícios tributários do programa Inovar-Auto e os princípios da Nação Mais Favorecida e do Tratamento Nacional: uma análise dos argumentos dos Painéis atualmente em Curso contra o Brasil no Órgão de SoluÇão de Controvérsias da OMC . 211 Eric Moraes Castro e Silva

A ERA DA HUMANIDADE: REFLEXões PARA A HISTÓRIA DO DIREITO INTERNACIONAL 236 Henrique Weil Afonso

Precedentes vinculantes nos Estados Unidos da América e no direito brasileiro: Um ESTUDO COMPARADO 264

Patrícia Perrone Campos Mello 
IL DIRITTO AMBIENTALE SECONDO L'OTTICA DEL DIRITTO COSTITUZIONALE POSITIVO E LA RESPONSABILITÀ PER DANNI ALL'AMBIENTE NEL DIRITTO COMUNITARIO: LO STATO DELL'ARTE DEL DIRITTO AMBIENTALE COSTITUZIONALE E COMUNITARIO 287

Elcio Nacur Rezende

DA DESCONSIDERAÇÃo DA PERSONALIDADE JURÍDICA NAS RELAÇÕES CONSUMEIRISTAS BRASILEIRAS: ANÁLISE À LUZ DAS TEORIAS CLÁSSICAS

Daniel Amin Ferraz e Marcus Vinicius Silveira de Sá

ANALYSIS OF ADVANTAGES AND DISADVANTAGES OF FORUMS PRESCRIBED UNDER THE UNCLOS AND STATE PRACTICE: THE WAY AHEAD FOR INDIA ......................................................319

Vinai Kumar Singh

Do governo POR LEIS À governanÇA POR NúMERos: breve anÁlise do Trade in SERVICE AgreEMENT (TISA) ...............................................................................338 Jânia Maria Lopes Saldanha, Rafaela da Cruz Mello e Têmis Limberger

As DIRETIVAS EUROPEIAS COMO NORMA REGULADORA DO DIREITO ADMINISTRATIVO GLOBAL ..356 Alice Rocha da Silva e Ruth Maria Pereira dos Santos

O desenVolvimento da POlítica AGRícola COMUM dA UNião EUROPEIA 375 Tatiana de A. F. R. Cardoso Squeff

A imunidade de Jurisdição das organizaÇões internacionais FaCE AO Direito de aCESSO À JUSTIÇA 391

Fernanda Araújo Kallás e Caetano

O DIREITO INTERNACIONAL ENTRE O DEVER ÉTICO E A AÇÃo POLÍ́TICA: OS FUNDAMENTOS DE UM DEVER DE COOPERAÇÃO INTERNACIONAL NA FILOSOFIA POLÍTICA DE IMMANUEL KANT .405 Ademar Junior Pozzatti

EXTENSÃo E FRAGMENTAÇÃo NO CONTEXTO DA JURISDIÇÃO PENAL INTERNACIONAL .423 Marcus Vinícius Xavier de Oliveira

A DEFINiÇÃo JURÍdiCA DA "COMUNIDADE" .444 Nitish Monebhurrun, Michelle Lucas Cardoso Balbino, Fernanda Castelo Branco Araujo, Othon Pantoja, Míara Bogo Bruno e Cândida Dettenborn Nóbrega 
Comparative Study on Chinese Local Legislation of Science and Technology ProGRESS

LI Xiaoming e LI Yihan

O CONTROLE PENAL DO TRÁFICO DE PESSOAS: CONSTRUÇÃO JURÍDICA, INTERAÇÕES ORGANIZACIONAIS E COOPERAÇÃO INTERNACIONAL

Bruno Amaral Machado e Priscilla Brito Silva Vieira

Desativismo judicial: a extradição Battisti no Supremo Tribunal Federal .505 Francisco Rezek e Israel Paulino

A decisão norte-americana do Caso Myriad: novos paradigmas para a Proteção patenTÁRIA DO CÓDIGO GENÉTICO HUMANO E BIOTECNOLOGIA 514 José Carlos Vaz e Dias e Clarisse De La Cerda 


\title{
Analysis of advantages and disadvantages of forums prescribed under the UNCLOS and state practice: the way ahead for India*
}

Vinai Kumar Singh**

\begin{abstract}
The paper aims to provide advantages and disadvantages of various forums stipulated under the United Nations Convention on Law of the Sea $(\mathrm{UNCLOS})^{1}$ to settle disputes related to sea. Pursuant to unsuccessful long diplomatic negotiations among the South Asian States, this paper not only helps contexualize the debates the usefulness of dispute settlement forums under the UNCLOS, it also underline the importance of Section 3 of Part $\mathrm{XV}$ of the UNCLOS which allows the states to exclude few crucial subject matters viz., maritime delimitation, etc from the jurisdiction of forums stipulated under the UNCLOS. Hence, the study examines the usefulness of Declarations made by the States under the UNCLOS. The study further investigates the state practice on exclusion of subject "maritime delimitation" from compulsory settlement system of UNCLOS.
\end{abstract}

Keywords: ICJ. ITLOS. Arbitral Tribunal. Compulsory settlement. Maritime delimitation. CLCS. Exclusion. State practice.

\section{INTRODUCTION}

By July 2016, 88 States including India have made declaration under Articles 287, 298 and 310 of the United Nations Convention on the Law of the Sea (UNCLOS). These declarations were made by the States partly in response of indicating their preferences of forums mentioned in Article 287 of the UNCLOS. Among them, many States have already experienced the importance of the declaration which indicated preference of forums for settlement of maritime disputes, excluded military activities from compulsory settlement of UNCLOS, and clarified their position/understanding on certain provisions of UNCLOS. Compulsory settlement system under the UNCLOS is one of the central components of UNCLOS. The number of declarations revised by many States in recent years on many aspects of law of the sea seems to indicate that what India should do. This paper thus explores in what situations compulsory jurisdiction entailing binding decisions under the UNCLOS may or may not useful to India.

South Asian States except Bangladesh has not yet made declarations under Articles 287, 298 and 310 of UNCLOS. States are rapidly revising their declarations over the past twenty years, however its effectiveness are widely debated. In this paper, author synthesizes academic and practitioners insi-

Recebido em 03/11/2016
Aprovado em 07/12/2016

** Assistant Professor (Senior) and Deputy Director, Indian Society of International Law, New Delhi. E-mail: vinaikumarsingh@gmail. com
1 United Nations Convention on the Law of the Sea (adopted 10 December 1982, entered into force 16 November 1994) 1833 UNTS 397. 
ghts on effective declarations. Author argues that declarations under Articles 287, 298 and 310 does actually assist in preventing international litigations in unexpected forum/s.

Part XV of UNCLOS 1982 contains the dispute settlement clauses. Section 1 of Part XV, entitled "General Provisions", essentially requires States to settle disputes through diplomatic channels prior to referring the matter to the compulsory procedures prescribed in Section 2 of Part XV. Part XV describes that some subject matters (freedom of navigations, over-flight, and laying of submarine cables and pipelines; protection and preservation of marine environment; fishing; marine scientific research; maritime delimitation; and finally military activities) are essentially required to be settled through the forum prescribed by the UNCLOS i.e., third party dispute settlement (Section 2 of Part XV). Also this part allows States to exclude some subject-matters from the jurisdiction of forums prescribed by the UNCLOS (Section 3 of Part XV).

Accordingly, Part XV has been divided into three Sections. Section 1 prescribes some general obligations for States to seek mutual and voluntary dispute settlement. Section 2 provides for compulsory dispute settlement mechanisms that result into binding decisions ${ }^{2}$ and Section 3 exempts some subject matters from the applicability of Section 2 known as optional exclusions. Thus after the exhaustion of the measures prescribed for the voluntarily settlement of the disputes under Section 1 and subject to the exceptions carved out under Section 3, the disputes related to the interpretation or application of this Convention have to be compulsorily settled as per the mechanisms prescribed under Section 2. It is also important to underline the essence that after the exhaustion of the measures prescribed for the voluntary settlement of disputes under Section 1 and subject to the exceptions carved out under Section 3, the disputes related to the interpretation or application of this Convention have to be compulsorily settled as per the mechanisms prescribed under Section 2.

2 The binding and compulsory dispute settlement procedures were to be "the pivot upon which the delicate equilibrium of the compromise must be balanced" (Memorandum by the President of the Conference on doc. A/CONF.62/WP.9, UN Doc.A/CONF.62/ WP.9/Add.1 (1976) reprinted in 5 Third United Nations Conference on the Law of the Sea: Official Records at p. 122).

\section{BACKGROUND AND FORUMS OF DISPUTE SETTLEMENT UNDER THE UNCLOS}

Section 2 (Articles 286-296) of Part XV of the UNCLOS seeks compulsory settlement of disputes that result in binding decisions but the State parties have leverage to choose one or more forums or give preference among forums identified under the UNCLOS. Article 287 prescribes four mechanisms that could be used by member States to settle their disputes. These mechanisms are as follows:

- the International Tribunal for the Law of the Sea established in accordance with Annex VI of the UNCLOS

- the International Court of Justice

- an arbitral tribunal constituted in accordance with Annex VII

- a special arbitral tribunal constituted in accordance with Annex VIII for one or more of the categories of disputes specified therein. These categories are as follows: (1) fisheries, (2) protection and preservation of the marine environment, (3) marine scientific research, and (4) navigation, including pollution from vessels and by dumping. ${ }^{3}$

Thus, State Parties are required to declare their choice or choices among these options either at the time of signature, ratification or afterwards. ${ }^{4}$ However, if the disputing parties fail in agreeing on a forum for dispute settlement either by virtue of their declaration or mutually after the rise of dispute, such disputes will automatically be submitted to the arbitral tribunal constituted under Annex. VII. ${ }^{5}$ Thus, arbitration under Annex. VII will always be a default mechanism to settle the disputes in any case of discord as to the respective forums. The increasing awareness about the Declaration under Article 287 is growing among South Asian States. The declaration made under Article 287 (1) in respect of forums, however, can be withdrawn after three months of the deposition of the notice of revocation to the UN Secretary General. ${ }^{6}$

It is also important to note here that any declaration under Article 287(1) does not affect the obligation of

\footnotetext{
3 Article 1, Annex. VIII. Special Arbitration, UNCLOS 1982.

4 Article 287 (1), UNCLOS 1982.

5 Article 287 (3)\&(5), UNCLOS 1982.

6 Article 287 (6), UNCLOS 1982. It is also important to note that this revocation of declaration is different from the revocation of optional declaration under Article 298 (2) of the Convention.
} 
a State Party to accept the jurisdiction of the Sea-Bed Disputes Chamber under Part XI, Section 5. ${ }^{7}$ Thus the jurisdiction of the Sea Bed Dispute Chamber neither affects nor be affected by any such declaration. The declaration under Article 287 (1) only relates to the declaration of the appropriate forum for the compulsory settlement of disputes resulting in binding decisions.

The basic purpose for providing these options of forums under the UNCLOS is to assuage the concerns of many States in respect of some existing forums of dispute settlement. For instance, Cuba expressly stated that it does not accept the jurisdiction of the ICJ under Article 287. States were having different opinions during the negotiation of UNCLOS III as to the exact forum for the compulsory settlement of disputes. It seems essential to understand the basic aspirations and fears of States during negotiations that caused the inclusion of the provisions for four different forums for the compulsory settlement of disputes. It will help in evaluating those concerns in the current state of affairs before making any declaration by States. There were mainly four groups advocating different forums for the compulsory settlement of disputes. ${ }^{8}$ The first group was advocating for the conferment of jurisdiction to the International Court of Justice (ICJ) over the disputes related to the law of the sea. (Netherlands and Switzerland) This group pointed out the contribution of ICJ's decisions in the development of law of the sea. ${ }^{9}$ They emphasised the need for the uniformity of international jurisprudence and underlined the fear of conflicting decisions if other body would be entrusted with the powers of compulsory settlement of disputes. The similar concerns were also raised by some scholars of international law. ${ }^{10}$

\section{Article 287 (2), UNCLOS 1982.}

8 ROSENNE, S; SOHN, L. B. United Nations Convention on the Law of the Sea 1982: A Commentary. Dordrecht: Martinuus Nijhoff Publishers, 1989. p. 41-42; MERRILLS, J. G. International Dispute Settlement. $4^{\text {th }}$ ed. Cambridge: Cambridge University Press, 2005. p. 185. 9 MERRILLS, J. G. International Dispute Settlement. $4^{\text {th }}$ ed. Cambridge: Cambridge University Press, 2005. p. 8.

10 ODA, S. 'Dispute settlement prospect in the law of the sea'. The International and Comparative Law Quarterly, v. 44, n. 4, p. 863872, 1995. p. 864. He observed that: The rule of law based upon the uniform development of jurisprudence will be best secured by strengthening the role of the International Court of Justice, not by dispersing the judicial function of dispute settlement in the international community among various scattered organs. The Convention is so misguided as to deprive the Court of its role as the sole organ for the judicial settlement of ocean disputes by setting up a new judicial institution, the ITLOS, in parallel with the long-established
However, this advocacy for ICJ has been challenged mostly by developing countries. Their fear of pro-Western bias of the ICJ that was specially formed by the 1963 judgement of the Court in Northern Cameroons case (Cameroon v. UK) and the 1966 South West Africa cases (Ethiopia v. South Africa; Liberia v. South Africa) has eventually been the prominent reasons for most of the third world states to negate the ICJ as a forum for the compulsory settlement of the disputes. ${ }^{11}$ Moreover even the academic concerns in respect of fragmentation of international law was also well responded by international legal scholars. ${ }^{12}$

The second group was of the view that the 'new' law could be more efficiently handled by a new tribunal. They argued the need for the special law of the sea tribunal that would be less rigid, more democratic and representative and have better understanding of the new law of the sea. They also pointed out that the ICJ is only open to the States but in some law of the sea matters it would be important to allow international organisations, corporations and individuals the task that could not be fulfilled by the ICJ. In this context, it is important to note that the International Tribunal for the Law of Sea (ITLOS) statute provides standing for the suitable entities in proceedings before it. ${ }^{13}$

The third group pointed towards the rigidness of the standing courts or tribunals and thus advocated for the more flexible arbitration. (France and Madagascar) They were of the view that the standing courts or tribunals are too rigid because the parties could not choose the judges and are abide by the previously determined

Court.

11 KWIATKOWSKA, B. The international court of justice and the law of the sea: some reflections. The International Journal of Marine and Coastal Law (IJMCL), v. 11, n. 4, p. 491-532, 1996. p. 499.

12 CHARNEY, J. I. The implications of expanding international dispute settlement systems: the 1982 convention on the law of the sea. American Journal of International Law (AJIL), v. 90, n. 1, p. 69-75, 1996. Commenting upon the fear of fragmentation, she observed on p. 72 that "I doubt that the Tribunal for the law of the Sea or the other dispute settlement forums under the convention will fail to take appropriate account of public international law ... there is no reason to believe ... that the tribunals will substantially diverge from this body of law (international law). They are required to decide the cases in accordance with the Law of the Sea Convention and the public international law."

13 Article 20(2), Annex. VI. Statute of the International Tribunal for the Law of the Sea, UNCLOS 1982; To support the ITLOS as forum, Australia, Cyprus, USA, Yogoslavia, Peru, Zaire, Tunisia, Ecuador, and Fiji made their statements in the Plenary during the fourth session (1976). 
rules and procedures that are generally lengthy and tardy. The supporters of this view also argued that parties can also design an expeditious arbitration procedure that would result in the prompt decisions of their disputes. There was another group of States that considered that most of the provisions of the UNCLOS involved many technical issues and thus advocated for the functional approach that should take care of the technical necessities involved in any dispute. (France, German Democratic Republic, Japan, Bulgaria, Poland and Trinidad and Tobago).

By providing four different forums, it is expected that UNCLOS ensured its wider acceptance and also allowed States to manoeuvre their choices of forums for the compulsory dispute settlement. So any declaration by a State Party must take care of its own interest and its chances of comfort in getting prompt and judicious result that should reflect its legitimate aspirations from the Convention. Thus the assessment of pros and cons of the available options becomes necessary before any such declaration. The study now submits its primary findings as to the suitability of the forums with respect to India's interest.

However, initially at the Third Conference on the Law of the Sea, it was noted "States are reluctant to give up their control over diplomatic and political options for resolving disputes, and are more comfortable seeking political legitimization, rather than declarations of legal validity, for their actions". ${ }^{14}$ In other words, during the Third Conference, dispute resolution through negotiations received "overwhelming support". Though, recently, availability of a third party process is considered a deterrent for unilateral interpretation of the terms of the Convention (for example, US and China are continuously making unilateral interpretations of the provisions of the UNCLOS). A further justification for the third party process is the perception that it could be a way of protecting less powerful States when dealing with the new subject matter area or less developed jurisprudence on the subject (for instances continental shelf) in international law. On the other hand, there is a provision in the UNCLOS which prevents any misuse of the provisions of third party process. For instance,

14 NOYES, J. E. Compulsory third party adjudication and the 1982 united nations convention on the law of the sea. Connecticut. Journal of International Law, p. 675-676, 1989. p. 678; See also NOYES, J. E. The international tribunal for the law of the sea. Cornell International Law Journal, v. 32, p. 109-182. 1999. p. 119. provision regarding safeguards against abuse of legal process under the UNCLOS has recently been used as a tool to deter the States from unnecessary suits and also to protect coastal States against harassment. In the present circumstances, to a certain extent, the need for compulsory dispute settlement is certainly justified. In brief, recourse to international process provides a check on powers granted to States as well as provide a means to protect those powers.

India made a declaration upon ratification of the UNCLOS on 29 June 1995:

a) The Government of the Republic of India reserves the right to make at the appropriate time the declarations provided for in articles 287 and 298, concerning the settlement of disputes;

b) The Government of the Republic of India understands that the provisions of the Convention do not authorize other States to carry out in the Exclusive Economic Zone and on the Continental Shelf military exercises or manoeuvres, in particular those involving the use of weapons or explosives without the consent of the coastal state.

The question arise before India that is the present India's declaration sufficient to protect the India's interest or requires a comprehensive declaration on the choice of forums which may declare specific subjects to be covered and not to be covered by these choice of forums.

\section{Analysis of Advantages and Disadvantages of Forums Prescribed under the UNCLOS and State Practice}

\subsection{Option 1: Arbitration under Annex. VII}

Advantages and Disadvantages: The reasons identified may be advantageous and at the same time it may be counter-productive in similar circumstances. In other words, the reasons identified for advantages for one or other forums in some instances/circumstances can become disadvantageous in other circumstances because the reasons advanced for in support or against may not impact the subject in similar manner in all circumstances. The advantages and disadvantages of any procee- 
dings depend on the facts of each case. For instances, third party interventions in proceeding may in some cases be useful for the disputant party or sometime be adverse to the interest of State. However, this study attempts to highlight in general sense the reasons advanced for and against the forums stipulated in Article 287 of the UNCLOS.

1. Expenses: As party to the UN Charter and the UNCLOS, India is already contributing its share towards the functioning of ICJ and ITLOS. If India opts for arbitration, there must be some concrete justification to further incur additional expenditure in the arbitration proceeding constituted under Annex. VII. Thus, as per the provisions of Annex VII, the arbitral tribunal consists of five persons. Each disputing party appoints one member to the tribunal and the rest three are appointed jointly by the disputing parties. ${ }^{15}$ For these appointments, States have to incur extra expenditures for their services. In brief, Arbitration tribunals involve high costs and high fees paid to arbitrators and court registrars, together with rental expenses of premises in which proceedings are carried on, secretarial and interpreting services, are well known for the adverse effect they have on public opinion. To the contrary, costs of the ICJ are borne by the UN. ${ }^{16}$

2. No Substantial Reasons: Also scholars and legal advisers throughout raise the concern that it may be difficult to justify regular financial contribution to the expenses of the ITLOS and ICJ without using them as a forum for dispute resolution. Arbitration will always demand the constitution of tribunal and each time state has to take extra steps in the constitution of the tribunal and thus to incur additional expenses, while at the same time paying towards maintenance of the ICJ and ITLOS.

3. Arbitration is more flexible than the procedure followed by the ICJ. Statute and Rules of which are defined in advance and are applied in the same manner to all cases brought before it. In the case of arbitration, particularly if a case is brought before the arbitral court on the basis of a special agreement, the parties have more freedom of movement and option, e.g., for a non-public procedure regarding court proceedings, which in fact is excluded from the framework of the Court of Hague.

15 Article 3 (b), (c) and (d), Annex. VII, UNCLOS 1982.

16 KARIOTIS, T. C. (Ed.) Greece and the Law of the Sea. Hague: Kluwer Law International, 1997. p. 170.
4. Confidentiality, Control on the Proceedings and Expediting the Process: As mentioned above, there are both pros and cons for arbitration proceedings. Arbitration proceedings are mostly confidential and remain completely in the hands of the disputing parties. This may sometimes be useful in the case, especially in maritime boundary disputes where, if the parties to such a dispute still have outstanding differences with other States over their maritime boundaries, they may well not want that the arguments that they use in the dispute settlement proceedings to be made public lest this may disadvantage their position in negotiations over their other outstanding unresolved maritime boundaries. ${ }^{17}$ From appointment of the arbitrators to the decision about procedures and rules of arbitration are remained under the control of the disputing parties.

However, in the extreme condition of discord between the disputing parties as to the appointment of three other members, the President of the ITLOS is authorised to appoint these members. ${ }^{18}$ These three members constitute the majority, thus the basic logic that the disputing parties have some control in the constitution of the arbitral tribunal stands little bit compromised. However, it also acts as impetus for the disputing parties to promptly agree on the remaining three members.

5. Delay the Process: However, it is possible that one party may use this process to delay the appointment of above-mentioned three arbitrators and get them appointed by the President of the ITLOS or other senior most judge of the tribunal in case the President belongs to the nationality of one of the disputing parties. ${ }^{19}$ This arbitration procedure, being default in the situation of discord as to the choice of respective forum under Article 287(1), can be invoked by any State party in diversified circumstances. In some circumstances, this option for the appointment by the President of ITLOS may be exploited with some ulterior motives.

6. Third Party Intervention: Arbitration does not permit third party intervention in any dispute as it may be done in proceedings before any standing courts and tribunals. This gives the disputing parties latitude to calibrate their arguments in different circumstances. Thus, if any State invokes some arguments against another State then a

17 FREESTONE, D. et. al. The Law of the Sea: progress and prospects. Oxford: Oxford University Press, 2006. p. 396.

18 Article 3 (e), Annex VII, UNCLOS 1982.

19 Article 3 (e), Annex VII, UNCLOS 1982. 
third state cannot intervene in this proceeding to take benefit without the wishes of the disputing parties. Hence, it provides flexibility and space to manoeuvre to States to settle their dispute. It also gives chances that similar kinds of disputes can be settled using different principles with different States. Thus, it may in some cases be advantageous and may also result into disadvantages.

7. Time bound: The arbitration proceedings under Annex VII are time bound and the traditional excuses of delays are not available under this process.

8. Default Mechanism: Apart from this, the option of arbitration under Annex VII, if invoked in default, prevents or does not give opportunity to the States to assess the advantages of use of other forums stipulated in Article 287 (1). Some scholars believe that except the fact that arbitration remains confidential, immuned from third party intervention and facilitates the disputing parties to use it as an ad hoc measure to solve the disputes, the resolution of the disputes by the arbitral tribunal under Annex VII seems not to offer any other prominent benefit to the disputing parties.

9. Lack of Institutional Commitment with the UNCLOS: Annex VII arbitration tribunal is unlikely to have the same degree of institutional commitment to the UNCLOS as a standing tribunal like the ITLOS. For instance, it is almost impossible to imagine the ITLOS downplaying the compulsory element in the dispute settlement under the UNCLOS in the way that the Annex VII arbitration tribunal did in the Southern Bluefin Tuna Case. ${ }^{20}$

10. Last but not least, any government may find it difficult to justify before public opinion the implementation of an unfavourable ruling issued by an arbitration court, which lacks the prestige of the ICJ. In other words, at last, whether win or lose the case, any government has to make extra effort to convince the public by interpreting the judgment/award or highlight the positive effect of the judgement/award of the tribunal, if any.

The author noted that the drafting history of the UNCLOS does not provide encouragement for default mechanism under Annex. VII, as the proposal made by the President of the Third United Nations Conference of the Law of the Sea in the Informal Single Negotia-

20 FREESTONE, D. et. al. The Law of the Sea: progress and prospects. Oxford: Oxford University Press, 2006. p. 398. ting Text (ISNT) on dispute settlement that the ITLOS should be default forum was emphatically rejected. ${ }^{21}$

Apart from the above-mentioned concerns, the indicative list (attached with this study as Table 1) of the respective declarations made by State parties also indicates the modest and gradual rejection of the arbitration under Annex. VII. In recent cases under the auspices of Annex VII Tribunal, its jurisdiction to hear the cases were contested vigorously by each of the defendant States concerned. While proceedings in Saiga and Swordfish maritime boundary delimitation cases have remained confidential so that it was not possible to know whether challenges to the jurisdiction of the these Annex VII arbitration hearing have been made. And subsequently these two cases were transferred by means of agreement between the parties to the ITLOS. ${ }^{22}$ In other words, the default jurisdiction vested to Annex VII arbitration is also not easily accepted by the States to resolve the law of the sea disputes. Most of the countries except erstwhile Soviet Block, Canada and Egypt, do not prefer arbitration under Annex. VII and declare their choice of either ITLOS or ICJ. Interestingly, Bangladesh has also declared ITLOS as its choice with respect to its disputes with India and Myanmar in the Bay of Bengal. Thus generally speaking, recent trends are in favour of choosing ITLOS as the forum to settle disputes. There are views that the declaration should be made indicating either of these two choices to avoid the default invocation of arbitration proceeding under Annex. VII. ${ }^{23}$

Above reasons advanced may require assessment of India's position in the context of its role/maritime aspirations. For instances, India with a large maritime boundary is a coastal State eager to protect and enforce its right in its coastal zones. At the same time, India is also an aspiring maritime power that strives for its significant presence in international waters (freedom of navigation). This increases the possibility of disputes with varied circumstances, possibilities and legal issues. It is not advisable each time to invoke the arbitration

21 FREESTONE, D. et. al. The Law of the Sea: progress and prospects. Oxford: Oxford University Press, 2006. p. 398.

22 Southern Bluefin Tuna Case (Australia and New Zealand v. Japan) Award on Jurisdiction and Admissibility, 4 August 2000 (2000) 39 ILM 1359; MOX Plant Case (Irelan v. United Kingdom) Order no. 3 of 24 June 2003; Cases concerning Land Reclamation by Singapore in and around the Straits of Johor (Malaysia v. Singapore), Request for Provisional Measures, Order of 8 October 2003.

23 FREESTONE, D. et. al. The Law of the Sea: progress and prospects. Oxford: Oxford University Press, 2006. 
proceedings under Annex VII in which economic burden and uncertainty of composition always hinge on its legitimate aspirations.

\subsection{Option 2: The International Court of Justice}

Now author in this the study weighs the suitability of ICJ. Though, ICJ has produced the significant and almost coherent jurisprudence on the maritime issues, it is basically a body that deals with issues in general international law, including those related to the law of the sea. However, the view has been expressed that the setting up of chambers under the revised new Rules of the ICJ in 1978 lacks the continuity and cohesion of the Court's case law. The delicate balances attained within the plenary Court, in which the most important forms of civilization are represented nowadays, cannot be realized in the case of setting up chambers consisting of 3 , 5 , or 7 members. ${ }^{24}$ Besides, for reasons of policy relating to States opting for the alternative of the chamber, certain judges might be favoured at the expenses of others, the latter remaining excluded. ${ }^{25}$ However, preferences shown by States for Chambers stopped in the 1990s and more recent cases being referred to the Plenary Court. They are persons with high moral character and have eligibility to be appointed as highest judicial officer in their respective countries or a jurist of competence in international law. However, it is difficult to guarantee that all the fifteen judges have the deep knowledge of the legal niceties of the Law of the Sea.

The ICJ is also a very time consuming process. Its involvement with other categories of disputes generally may delay the legal process relating to the law of the sea disputes. It is not always possible to get prompt and effective remedy from the ICJ. Moreover, it is the general perception that the ICJ is a very politicised body, so there are probabilities that some extra legal concerns may infiltrate the legal language of the Court. The control over the selection procedure of its members by the General Assembly and Security Council also does not immune it from considering bare political realities

24 The question of composition of the Chambers was considered both from theoretical point of view as well as by the Court itself in 1982, the US and Canada in the Gulf of Maine case. See SCHWEBEL, S. M. Ad hoc chambers of the international court of justice. AJIL, v. 81 , p. $831-854,1987$. p. 840 .

25 SCHWEBEL, S. M. Ad hoc chambers of the international court of justice. AJIL, v. 81, p. 831-854, 1987. p. 840. through legal language.

Apart from this, the procedural jurisprudence established by the ICJ, like its judgement in Monetary Gold (Preliminary Question) that established the principle that where a third State's legal interests would not only be affected by a decision but form the very subject matter of the decision, proceedings may not be maintained in the absence of that third State. The invocation of this principle in politically charged and much criticised East Timor judgement of 1995 still evince the political colour of the court.

The ICJ by virtue of its jurisprudence also left open the chances for the third State to intervene as a non party under Article 62 of the ICJ statute. In the 1990 judgement of the Gulf of Fonseca (Intervention), the ICJ Chamber for the first time granted a State (Nicaragua) permission to intervene as a non party under Article 62 of the ICJ Statute. Though subsequently the requests for the intervention has been dismissed in 1995, but this chance of third state non party intervention will always loom large to the prospects of any dispute resolution through ICJ. ${ }^{26}$ Also there are instances when the Court has taken the view not to decide the case on merits that compromises its chances for providing prompt and effective dispute resolution of the law of the sea disputes.

Moreover, Article 290 of the UNCLOS discusses the provisions for the issuance of the provisional measures. According to this, a Court or tribunal if satisfied about its own jurisdiction in the dispute may issue provisional measures on the request of a disputing party. ${ }^{27}$ To establish this link of jurisdiction is not always easy in case of the ICJ. Moreover, as per the ICJ statutes, any provisional measures prescribed by ICJ must also be reported to the Security Council. ${ }^{28}$ This unnecessarily further politicise the issue.

Probably, these chances of politicisation of disputes through ICJ have prompted some States to categorically declare their rejection of the ICJ as a forum for compulsory settlement of disputes. (see, attached Table 1, for Algeria and Cuba Declarations). Moreover, if one gives a cursory look to the respective declarations made

26 KWIATKOWSKA, B. The international court of justice and the law of the sea - some reflections. The International Journal of Marine and Coastal Law (IJMCL), v. 11, n. 4, p. 491-532, 1996. p. 510-511. 27 Article 290 (1), UNCLOS 1982.

28 Article 41, ICJ Statute 1945. 
by the Parties, it becomes quite clear that most of the developing countries have not preferred ICJ or have given it secondary priority. Thus, it seems that the probable political manoeuvring in ICJ and its non efficacy in giving prompt and effective remedy deter most of the developing States from declaring ICJ as a cherished forum for dispute settlement under UNCLOS. ${ }^{29}$

Importantly, the question of optional jurisdiction of the ICJ as one of the alternative forums to settle the disputes related to the law of the sea was discussed at the First Conference of the UNCLOS. ${ }^{30} \mathrm{At}$ the Conference, referral of law of the sea disputes to the ICJ due to its optional jurisdiction was considered inappropriate to accord it mandatory jurisdiction. However, India, by way of compromise, proposed that a proviso be added to the Article to the effect that the jurisdiction of the ICJ should be subject to Article 36 of the ICJ Statute. ${ }^{31}$ This discussion led the debate how far the declarations made by the States under optional jurisdiction of the ICJ could lead or prevent the subject matter for the jurisdiction of the ICJ.

Only 72 out of 193 United Nations member states, about 26 percent, have declarations of acceptance of ICJ jurisdiction under Article 36(2) of the ICJ Statute. Declarations have been made unconditionally or on condition of 'reciprocity' on the part of several or certain States. Thus, for example, if Egypt has not accepted the compulsory jurisdiction, then even if Portugal has accepted it, the ICJ would not have jurisdiction over a dispute between Portugal and Egypt. States have frequently made reservations excluding disputes arising before a certain date or even if the disputes arises after such a date, if it arise out of facts or situations existing before that date (see the Belgian reservation), the disputes prior to that date or falling within specified situations would be out of the Court's jurisdiction. Declarations can be for a specified period of time, like Brazil's declaration was made to be in application for a certain period. Another example is condition of reciprocity for instance Norway Declaration. The UK declaration contains both these reservations. ${ }^{32}$ In brief, jurisdiction of

29 KARIOTIS, T. C. (Ed.) Greece and the Law of the Sea. Hague: Kluwer Law International, 1997. p. 175.

30 KLEIN, N. Dispute Settlement in the UN Convention on the Law of the Sea. Cambridge: Cambridge University Press, 2005. p. 15.

31 KLEIN, N. Dispute Settlement in the UN Convention on the Law of the Sea. Cambridge: Cambridge University Press, 2005. p. 15. India Proposal, UN Doc. A/CONF.13/C.4/L.61.

32 COLLIER, J.; LOWE, V. The Settlement of Disputes in International
ICJ will rest on the scope of declaration of each state. This would also indicate that ICJ forum may serve limited purpose at present.

Apart from this the forum of ICJ always makes any dispute very high profile. Though there is no hierarchy in international law and even the judgements of the ICJ or ITLOS are binding only on parties to the dispute, but the mere invocation of the ICJ put the dispute on high pedestal. This may involve emotional involvement of citizenry of the disputing parties and thus may also become the issue in domestic politics. It will unnecessarily complicate the enforcement mechanism and further may compromises the prospect of peace.

Advantages: Through special agreement under Article 36(1) of the Statute to submit the dispute to the ICJ has the advantage of the dispute being concisely defined in the special agreement. In fact, contesting parties may agree through the special agreement and in advance on the exact extent and content of their dispute, avoiding thereby subsequent submission of preliminary exceptions by the defendant, as can happen and has often taken place in cases of unilateral applications. During negotiations for special agreement, both litigants may agree to refer only part of their dispute to the Court, leaving final settlement to their own discretion.

\subsection{Option 3: The International Tribunal for the Law of the Sea (ITLOS)}

1. Expertise: The ITLOS is a special tribunal for the law of the Sea and it consists of twenty one members. These members must be the persons of high moral character and have recognised competence in the Law of the Sea. Thus, the recognised competence in the Law of the Sea is an essential condition for becoming the member of the tribunal. Article 289 of the UNCLOS encourages the use of scientific or technical experts who may sit with the judges but without a vote. ${ }^{33}$ This gives it more expertise in comparison to ICJ in the matters of the law of the sea.

2. Representative in Nature: The constitution of the ITLOS is also much representative in comparison to ICJ. There is no condition in ITLOS that judges of par-

Law: Institutions and Procedures. Oxford: Oxford University Press, 1999. p. 141.

33 ANDERSON, D. Modern Law of the Sea. Leiden: Martinus Nijhoff, 2008. p. 514. 
ticular nationalities will always be there on the Bench as is the case with the ICJ in respect of the permanent members of the Security Council. The members of ITLOS are elected by the secret ballot by the member States. The constitutive Articles also guarantees the minimum number of members from each geographical region. According to the present scheme of affairs, there must not be less than three members from each of the following groups. These groups are:

(i) African States, (ii) Asian States, (iii) Eastern European States, (iv) Latin American and Caribbean States, (v) Western European States, and (vi) other States.

3. Avoidance of multiplicity of forum: The composition of ITLOS is more democratic and represents the interests of State Parties in a better way than that of ICJ. The record of the ITLOS is also very persuasive in this respect. Moreover, in most of the cases of provisional measures and prompt release of vessels and crew, ITLOS almost have a compulsory jurisdiction. So there may always be a need to deliberate before ITLOS in respect of these measures. Thus, any preference of other forums may engage India in two different forums at two successive junctures. It unnecessarily increases the burden to be involved in two different forums for a similar dispute.

4. Special Reason for Developing Countries: Apart from this, ITLOS is a new specialised body of the UNCLOS. The selection of its members is governed totally by democratic processes that remain under the control of each and every member State in equal capacity. Probably these are the decisive concerns that made most of the developing countries to declare ITLOS as their choice for compulsory settlement of disputes.

5. Autonomy: ITLOS is a completely separate entity created by the Convention but not an organ of a larger organization, such as the UN, the Council of Europe or the European Community. Such autonomy may bring the advantages of genuine independence. At the same time, autonomy increases the numbers of arrangements which have to be put in place at present. Autonomy may also mean that the ITLOS has only the periodic meetings of the State Parties from which to seek help should any unexpected problem arises. ${ }^{34}$

6. Access to the ITLOS: The jurisdiction of the ITLOS is wide enough to cover non-State entities, such as the

34 ANDERSON, D. Modern Law of the Sea. Leiden: Martinus Nijhoff, 2008. p. 508.
International Seabed Authority, mining consortia or the EC.

7. Application of other Rules of International Law and Local Remedies Rule: Article 293 provides that courts and Tribunals with jurisdiction under the Convention are to apply both in terms "and other rules of international law not incompatible with" the Convention. One example of such other rules is provided by Article 295 which imports into the procedures the well-known "local remedies" rule, according to which an available local remedy has to be sought before the recourse is taken to an international body. Article 293 means, in practice, that the ITLOS will have to consider not only the law of the sea, including customary law on certain matters, but also a wide range of other legal issues. These include: the law of treaties (for instance, the interpretation or application of the Convention as a treaty subject to the Vienna Convention on the Law of Treaties; or the effects of national declarations); the effects of previous judicial decisions (as in case decided by a Chamber of the ICJ about the Gulf of Fonesca); and the law of State responsibility, of which the local remedies rule forms part. $^{35}$

8. Cost Effectiveness: The idea of "cost effectiveness" has been taken from the Agreement of July 1994 on the Implementation of Part XI of the Convention. Section 1 of the Annex to this Agreement requires all institutions constituted by the Convention to be cost effective. This provision applies therefore to the ITLOS as well. In practice, the ITLOS is expected to adopt procedures which avoid unnecessary expenses, both for the litigants and the State parties which fund the ITLOS.

9. Compliance by the Disputant Parties with the Decision of the ITLOS: Article 95 requires each party to a case to report to the ITLOS upon its compliance with any provisional measures prescribed under Article 290 of the UNCLOS.

As per the provisions of the Convention, if the disputing parties may not agree upon the similar mechanism for the dispute settlement, the arbitration under Annex VII will be invoked automatically. Thus not to take risk of the arbitration procedure and to use the more democratic and specialised forum, the study finds it appropriate to declare ITLOS as a primary forum for

35 ANDERSON, D. Modern Law of the Sea. Leiden: Martinus Nijhoff, 2008. p. 509. 
the settlement of disputes. This will allay the uncertainty as to the forums because it fits with the declarations of the most of the States that also choose ITLOS.

\subsection{Option 4: Special Arbitration under Annex VIII}

In respect of disputes related to particular subject matters (disputes concerning fisheries, protection of marine environment, marine scientific research and navigation), the procedure of special arbitral tribunal under Annex VIII seems, preferred by States. This method of settlement is known as 'functional approach' to dispute settlement under the law of the Sea. A partial attempt was made in the third 1958 Geneva Conventions on the Law of the Sea, which provided for the appointment of experts to decide the disputes relating to fishing and conservation of living resources of the sea. When such a dispute arose, the procedure laid down by that Convention envisaged a special commission of five members established by agreement between the parties. The members were to be drawn 'from among qualified persons being nationals of states not involved in the dispute and specializing in legal, administrative or scientific questions relating to fisheries, depending upon the nature of the dispute to be settled'. The decisions of special commissions were to be made in accordance with scientific and technical criteria set out in the Convention and were binding on the States concerned. This functional approach to dispute settlement is taken considerably further in Annex VIII of the UNCLOS, 1982 concerning special arbitration. ${ }^{36}$

The idea of 'functional approach' was supported by some States in the Working Group of 1974 Caracas Session (the second session of the UNCLOS) which envisaged that certain law of the sea disputes will be more amenable to settlement by a panel of technical experts rather than by judges in courts or tribunals. Thus, the Working Group supported the 'functional approach' to dispute settlement under the UNCLOS instead of 'general approach'. They also believed that not all law of the sea disputes are suitable for settlement exclusively through formal courts of law or tribunals. The question of relationship between these two approaches was addressed by the Working Group subsequently. In

36 MERRILLS, J. G. International Dispute Settlement. $4^{\text {th }}$ ed. Cambridge: Cambridge University Press, 2005. p. 196-197. the course of the Working Group discussion, it was pointed out that the functional approach relied upon a rather rigid and artificial classification of disputes into categories which could be difficult to apply in certain real situations. An example was given where a foreign fishing vessel alleged to have violated certain fishing regulations under the UNCLOS is also alleged to have engaged in marine pollution and also interfered with the navigation use of the sea. In this situation, it is not certain whether the resulting dispute is to be classified as a fisheries dispute or marine pollution dispute or a navigation dispute. Thus there would be problems in deciding first which of the functional procedures had jurisdiction over the dispute, or problems with litigation if it is decided that separate proceedings be conducted against the same vessel in each of the functional procedures concerning the respective alleged violations. ${ }^{37}$

Special arbitration is one of the binding methods of settlement and will normally be adjudicative. To assist States in setting up a tribunal, list of experts in each of the four fields are to be maintained by, respectively, the Food and Agriculture Organization, the UN Environmental Programme, the Inter-Governmental Oceanographic Commission and the International Maritime Organization. Each State party may nominate to each list two experts 'whose competence in the legal, scientific or technical aspects' of the fields is established and 'who enjoy the highest reputation for fairness and integrity' (Article 3). It seems that the arrangements for constituting a tribunal essentially follow the pattern of conciliation, rather than arbitration, in that each party selects two members, preferably from the appropriate list, and the president is chosen by agreement. Similarly, vacant places must be filled from the appropriate list by the Secretary General of the UN and not the President of the ITLOS.

Article 5 of Annex VIII provides that in certain circumstances its functions can be broadened to include fact-finding and conciliation. By agreement the parties may set up a special arbitral tribunal to carry out an inquiry into the facts of any dispute of a type amenable to special arbitration. Such a tribunal's findings of fact are conclusive as between the parties. Thus, the clear advantage of machinery of special arbitration is its additional form of conciliation.

37 ADEDE, A. O. The System for Settlement of Disputes under the United Nations Convention on the Law of the Sea. Netherlands: Martinus Nijhoff Publishers, 1987. p. 27-28. 
It is submitted that it is appropriate to leave questions involving the discretion of coastal State to a special tribunal in matters related to fishing, marine scientific research, and the prevention of pollution since consideration of equity rather than law is involved.

\section{Maritime Delimitation}

As mentioned above, Article 298 of the UNLOS allows States Parties to exclude certain categories of disputes from compulsory procedures. States may declare when signing, ratifying or acceding to the Convention, or at any time thereafter, that they do not accept the procedures available under Section 2 for those disputes in Article 298. Declarations permitted under Article 298 relate, to maritime delimitation disputes in relation to the territorial sea, EEZ or continental shelf of States with opposite of adjacent coasts as well as disputes involving historic bays or title. ${ }^{38}$ Importantly, the dispute-related provisions to special rights in EEZ (rights, jurisdiction and duties of coastal State set in Article 58 of UNCLOS) will be covered by Article 297 (1) and not by Article 298 (1)(a). ${ }^{39}$ In addition, the scope of Article 298(1)(a) is limited that a State will only be obliged to submit dispute to Conciliation procedure which suggest that proposed agreement (on the basis of Conciliation Commission) does provide for a procedure entailing a binding decision only upon mutual consent. In other words, however, importantly, Conciliation Commission's recommendations cannot be subjected directly to judicial review. ${ }^{40}$ Still the UNCLOS allows States an option to exclude the subject covered under Section 298(1) (a). Importantly, need to also highlight that Article 298 title is not "Optional Exception" rather title is "Optional Exception to Applicability of Section 2 ". ${ }^{41}$

38 It will also apply to outer continental shelf by analogy.

39 ROSENNE, S; SOHN, L. B. United Nations Convention on the Law of the Sea 1982: A Commentary. Dordrecht: Martinuus Nijhoff Publishers, 1989. p. 109.

40 SUAREZ, S. V. The Outer Limits of the Continental Shelf: Legal Aspects of their Establishment. Heidelberg: Springer, 2008. p. 250.

41 The Socialist States indicated that, "they would not accept any formula -nor indeed the whole convention - if it contained provisions on compulsory procedure entailing binding decisions relating to delimitation disputes". This problem became particularly acute when the decision was reached that no reservations could be made to the UNCLOS. The compromise reached was that maritime delimitation and historic title disputes would be included with

\subsection{India and the Commission on the Limits of Continental Shelf}

On 11 May 2009, the Republic of India submitted to the Commission on the Limits of the Continental Shelf (CLCS), in accordance with Article 76, paragraph 8 , of the UNCLOS, information on the limits of the continental shelf beyond 200 nautical miles from the baselines from which the breadth of the territorial sea is measured, ${ }^{42}$ with the following statement:

According to the submitting State, this is a partial submission and, as a coastal state in the Southern part of the Bay of Bengal, India reserves the right to make at a later date, notwithstanding the provisions regarding the ten-year period, a separate submission on the outer limits of its continental shelf, based on the provisions of the Statement of Understanding contained in Annex II to the Final Act of the Third United Nations Conference on the Law of the Sea.

India has reserved the right to make a separate second partial submission of information and data to support the outer limits of continental shelf in accordance with the provisions of the Statement at a later date, notwithstanding the provisions regarding the ten-year period. ${ }^{43}$

India has established continental shelf beyond 200 nautical miles in the following regions: Eastern Offshore Region comprising the eastern offshore region of Mainland India in the Bay of Bengal and the Western Offshore Region of Andaman Islands; and Western Offshore Region of India in the Arabian Sea. ${ }^{44}$

India also mentions in its submission that, although India has entered into a series of agreements with its

the compulsory dispute settlement framework but States could optionally exclude these disputes, subject to an obligation to refer the matter to conciliation if certain conditions were met. Interestingly, Section 2 of Part XV purports to require the use of the procedure entailing a binding decision, on the other hand, the whole purpose of the optional exception and the use of conciliation is to exclude resort to compulsory procedure.

42 It should be noted that the Convention entered into force for India on 29 July 1995.

43 The Indian Continental Shelf, Partial Submission to the Commission on the Limits of the Continental Shelf, pursuant to Article 76, paragraph 8 of the United Nations Convention on the Law of the Sea, Executive Summary, Part 1, 2009.

44 The Indian Continental Shelf, Partial Submission to the Commission on the Limits of the Continental Shelf, pursuant to Article 76, paragraph 8 of the United Nations Convention on the Law of the Sea, Executive Summary, Part 1, 2009. paragraph 7. 
many neighbouring coastal States but outer limits of continental shelf with Pakistan, Oman, Sri Lanka, Bangladesh and Myanmar are yet to be settled. It further states that this submission has been made without prejudice to the matters of delimitation with its neighbouring states. ${ }^{45}$ Pakistan, and Oman have also made submissions of similar pattern. This indicates that States generally make Submissions to the Commission without compromising with their right to delimit the continental shelf through peaceful means or compulsory binding procedures.

After India made its Submission to the Commission; Myanmar, Bangladesh and Oman objected to it and they requested the Commission to consider this submission without any prejudice to the continental shelf areas that these countries are entitled to. ${ }^{46}$ India is yet to receive the recommendations from the Commission.

\subsection{Conciliation Commission under Annex $V$ of the UNCLOS and Overlapping Continental Shelf}

Article 298 allows State to exclude the disputes concerning the interpretation or application of Articles 15, 74 (Delimitation of EEZ between States with opposite or adjacent coasts) and 83 (Delimitation of Continental Shelf between States with opposite or adjacent coasts). Article 298 does not make reference to Article 76 which gives definition of Continental Shelf. This allows some scholars to buy an argument that there is no provision for an exclusion of disputes related with outer limits of continental shelf from the judicial recourse to any of the compulsory procedure enumerated under Article 287". ${ }^{47}$ However, Article 298 does refer to exclude disputes related with Article 83 where issues of overlapping continental shelf areas arise. This exclusion can be done by making a declaration in writing to this effect in accordance with Article 298(1)(a). In that case, Article 298 applies, with its provision for compulsory recourse to conciliation under Annex V. Once provision related to Conciliation triggered, States cannot refer the matter to compulsory procedures entailing a binding decision unless they so agree.

45 The Indian Continental Shelf, Partial Submission to the Commission on the Limits of the Continental Shelf, pursuant to Article 76, paragraph 8 of the United Nations Convention on the Law of the Sea, Executive Summary, Part 1, 2009. p. 4.

46 Communications made by Myanmar, Bangladesh and Oman with respect to the Submission made by India to the Commission. 47 SUAREZ, S. V. The Outer Limits of the Continental Shelf: Legal Aspects of their Establishment. Heidelberg: Springer, 2008. p. 230.

\subsection{Maritime Delimitation and Choice of Forums: India}

On 29 October 2015, an Arbitral Tribunal issued its award on the questions of jurisdiction and admissibility in the arbitration between the Republic of Philippines and the People's Republic of China concerning the South China Sea. In brief, the Tribunal found that it had jurisdiction to decide seven of the Philippines' fifteen substantive claims. In this case, according to China's Position Paper ${ }^{48}$, China contended that the dispute was properly characterised as relating to maritime boundary delimitation which, for the reasons given below, was excluded from the Tribunal's jurisdiction by an exclusionary provision in the UNCLOS that China had activated in $2006 .{ }^{49}$

In rejecting this contention, the Tribunal distinguished between a dispute concerning the existence of an entitlement to maritime zones (the present matter), and a dispute concerning the delimitation of those zones where parties' entitlements overlap. The Tribunal also emphasised that, while it would determine the nature of particular maritime features in dispute, insofar as this resulted in overlapping entitlements between the parties the Tribunal's determination would not go so far as to delimit boundaries. ${ }^{50}$

Therefore, it should be drawn from this case that even if a State excludes jurisdiction under Article 298 of UNCLOS, it will continue to apply between claimant States concerning the interpretation or application of the provisions of UNCLOS which are not within the exclusion in Article 298. They include ${ }^{51}$ :

48 Position Paper of the Government of the People's Republic of China on the Matter of Jurisdiction in the South China Sea Arbitration initiated by the Republic of Philippines, 7 December 2014. <http://www.fmprc.gov.cn/mfa_eng/zxxx_662805/t1217147. shtml>.

49 Position Paper of the Government of the People's Republic of China on the Matter of Jurisdiction in the South China Sea Arbitration initiated by the Republic of Philippines, 7 December 2014. <http://www.fmprc.gov.cn/mfa_eng/zxxx_662805/t1217147. shtml>.

50 Position Paper of the Government of the People's Republic of China on the Matter of Jurisdiction in the South China Sea Arbitration initiated by the Republic of Philippines, 7 December 2014. <http://www.fmprc.gov.cn/mfa_eng/zxxx_662805/t1217147. shtml>.

51 BECKMAN, R. 'UNCLOS dispute settlement system' in International Conference of the South China Sea: UNCLOS and State Practice' Organized by National Institute for South China Sea Studies Haikou. October 24-25, 2013 < http://cil.nus.edu.sg/wp/ 
1. A dispute on whether a feature meets the definition of an island under Article 121(1) because it is a naturally formed area of land, surrounded by water, which is above water at high tide.

2. A dispute on whether an island is a rock which cannot sustain human habitation or economic life of its own within Article 121(3) and is therefore not entitled to an EEZ or continental shelf of its own.

3. A dispute on whether a feature is a low-tide elevation pursuant to Article 13.

4. A dispute on whether the use of straight baselines by a State is consistent with Article 7.

5. A dispute on the interpretation or application of Article 6 on reefs.

Therefore, this widely read award of the Arbitration in South China Sea Case ${ }^{52}$ have provided a rare opportunity to analyse the scope of declaration made under Article 298. Hence it is safe to assume that it is not certain that through declaration of exclusion from forums will remain excluded in all circumstances from the scope of third party adjudications. Undoubtedly, this award will influence policy discourses in States reliance on declaration.

Importantly, the beauty of Article 298 paragraph 1(a) provides for Compulsory Conciliation which could be as effective as other options under the UNCLOS to settle the law of the sea disputes. Compulsory Conciliation puts equal political pressure and needs equal efforts as that of compulsory binding settlement procedures. Therefore, the option of excluding the jurisdiction under Article 298 should be ruled out. In support of third party adjudication or judicial settlement of maritime disputes, Charney concludes that the delimitation of maritime zones has been subject to third-party dispute settlement in the past despite the highly discretionary nature of the applicable legal principles. ${ }^{53}$ This history could indicate that the subject of the dispute would be conducive to settlement under the compulsory procedures in Part XV of the UNCLOS. Klein in her study

wp-content/uploads/2014/08/Beckman-NISCSS-Hainan-Oct2013-submitted.pdf $>$.

52 In the Matter of the South China Sea Arbitration, PCA Case $\mathrm{N}^{\circ} \quad 2013-19 . \quad<$ https://pca-cpa.org/wp-content/uploads/ sites/175/2016/07/PH-CN-20160712-Award.pdf>.

53 CHARNEY, J. I. Progress in international maritime boundary delimitation law. American Journal of International Law, v. 88, p. 227256, 1994. p. 228. clarified that this may well be another contributory factor as to why governments negotiating at the Third Law of the Sea Conference did not insist on the complete exclusion of maritime delimitation dispute from the compulsory dispute settlement regime. ${ }^{54}$

Another possible approach that could be, keeping in view India's economic, political and strategic sensitivity in surrounding oceans where the overlapping claims by neighbouring countries are possible, some of the areas (keeping in mind India's emotive considerations) may be excluded from third party jurisdiction. This is legally justified as Article 298 (1) (a) (i) makes impliedly that a State may exclude the sensitive dispute with one of its neighbours but does not want to offend its other neighbours by a broad-gaged exclusion. Article 298(1) (a) (i) says that where disputes relating to sea boundary delimitations are separated by a disjunctive "or" from disputes involving historic bays or titles, thus enabling a State to select only one of these subcategories for an exclusion through its declaration. ${ }^{55}$ Even if above mentioned implied understanding is questioned, it can be argued, undoubtedly, that this is a grey area (gap in law) where UNCLOS has not made explicit rules and limited declaration of this nature may be best way to protect sensitive areas of India' seas. On this basis, India may exclude one or two maritime areas (and not all maritime areas with all of its neighbours).

\section{Declarations of States Parties Relating to Settlement of Disputes in Accordance with Article 298 (Optional Exceptions to the Applicability of Part XV, Section II of the (onvention): State Practice}

From above-mentioned Table 2, there are 25 States out of 60 States which have made declarations under Article 298 and have excluded the disputes related to maritime delimitation from the compulsory procedure. Out of 25 States, there are 7 States who have not even made the choice of forums. (China, France, Gabon, Republic of Korea, Republic of Palau, Saudi Arabia and

54 KLEIN, N. Dispute Settlement in the UN Convention on the Law of the Sea. Cambridge: Cambridge University Press, 2005. p. 254.

55 ROSENNE, S; SOHN, L. B. United Nations Convention on the Law of the Sea 1982: A Commentary. Dordrecht: Martinuus Nijhoff Publishers, 1989. p. 115. 
Thailand). Author makes an attempt to summarize the existing statistics as follows:

1. The expressions (over enthusiasm for exclusion) from these 7 States reflects their position in this connection either they believe that the compulsory procedure may be counterproductive or more political/ sovereignty/security aspects are connected or as a precaution this measure is required or they have settled their disputes and don't want to open the subject once again for the settlement.

Out of 60 States, there are 5 States (Austria, Belgium, Cape Verde, Nicaragua and UK) who have not excluded the subject from compulsory procedure and also have given their choice of forums. These States have chosen forums either ITLOS or ICJ or both where majority of States have given preference to ITLOS as a forum.

Out of 60 States, there are 30 States that have not expressly made any declarations under Article 298 either of exclusion or non-exclusion. Among 30 States who have not made declarations under Article 298, 4 states have not even given choice of forums i.e, there are 26 States out of 30 States who have given choice of foru$\mathrm{ms}$ but have not shown interest in making declarations. These 26 States can be considered as not against per se exclusion of maritime delimitation disputes. Need to note that Article 298 is declaration of exclusion; until a declaration is made excepting some disputes, these disputes remain within the jurisdiction of the appropriate tribunal designated in accordance with Article 287 of the Convention. ${ }^{56}$ In this situation, absence of declaration would amount to non-exclusion of subject from compulsory procedure. Hence, 51 States can be understood who have not shown interest in excluding the subject (maritime delimitation) from compulsory procedure. The author identified various reasons that can be advanced for this position:

a. Article 298 (1)(a) scope is limited in a sense that a State will only be obliged to submit the dispute to conciliation proceeding and the proposed agreement by the Conciliation Commission will not be binding on States.

b. One of the legal reason for non-exclusion can be that the past dispute before the UNCLOS has been completely excluded from the scope of Article 298(1)(a).

56 ROSENNE, S; SOHN, L. B. United Nations Convention on the Law of the Sea 1982: A Commentary. Dordrecht: Martinuus Nijhoff Publishers, 1989. p. 141. c. It could be argued this optional exclusion potentially denies a range of advantages otherwise accruing to States in dispute but is a realistic reflection of State preferences for political, rather than third-party adjudication when dealing with an important matter such as title. There is a strong belief that marine resources are very important for States and required optimal exploitation for its nation development. In their view, keeping it away from the scope of Article 298(1)(a) will not serve any purpose for States. The importance of international marketability illustrates why non-exclusion is an essential complement to maritime delimitation. Without legal resolution, a State may lose all capacity to harvest and market resources - or at best the questionable title will significantly diminish the value of the concession - and this is because it can no longer market exclusive rights to private fishing fleets or oil companies. ${ }^{57}$

d. Overlapping entitlements "the most dangerous disputes" as they lie "at the very heart of sovereignty" may not remain issues for these States. ${ }^{58}$

In Europe, except France, Denmark (excluded only from Arbitration under Annex VII), Portugal, Italy, and Norway, majority of west European States have not excluded the compulsory procedure of the UNCLOS. As history suggests these five States have grave pain in settlement of disputes related to maritime delimitation which essentially become emotive issues. Also these States have in principle settled the issue by Court or through agreements, and they believe there is no need to re-agitate the dispute. ${ }^{59}$

In brief, it can be suggested that India should not exclude the dispute related with maritime delimitation mentioned in Article 298(1)(a) of the UNCLOS.

However, there are States who have made declaration under Article 310 which may have intended to either strengthen their positions to either exclusion or non-exclusion of maritime delimitation disputes from the scope of Article 298(1)(a). ${ }^{60}$

57 KLEIN, N. Dispute Settlement in the UN Convention on the Law of the Sea. Cambridge: Cambridge University Press, 2005. p. 255.

58 KLEIN, N. Dispute Settlement in the UN Convention on the Law of the Sea. Cambridge: Cambridge University Press, 2005. p. 256.

59 Maritime Delimitation in the Area between Greenland and Jan Mayen (Denmark v. Norway), ICJ, Verbatim Record, p. 50-78.

60 China:

1. In accordance with the provisions of the United Nations Convention on the Law of the Sea, the People's Republic of China shall enjoy sovereign rights and jurisdiction over an exclusive economic zone of 200 nautical miles and the continental shelf. 


\subsection{EEZ and Possible Approach by India}

2. The People's Republic of China will effect, through consultations, the delimitation of the boundary of the maritime jurisdiction with the States with coasts opposite or adjacent to China respectively on the basis of international law and in accordance with the principle of equitability.

3. The People's Republic of China reaffirms its sovereignty over all its archipelagos and islands as listed in article 2 of the Law of the People's Republic of China on the territorial sea and the contiguous zone, which was promulgated on 25 February 1992.

Malaysia:

7. The Malaysian Government interprets article 74 and article 83 to the effect that in the absence of agreement on the delimitation of the exclusive economic zone or continental shelf or other maritime zones, for an equitable solution to be achieved, the boundary shall be the median line, namely a line every point of which is equidistant from the nearest points of the baselines from which the breadth of the territorial sea of Malaysia and of such other States is measured.

Malaysia is also of the view that in accordance with the provisions of the Convention, namely article 56 and article 76, if the maritime area is less [than] or to a distance of 200 nautical miles from the baselines, the boundary for the continental shelf and the exclusive economic zone shall be on the same line (identical).

Malta:

The Government of Malta interprets article 74 and article 83 to the effect that in the absence of agreement on the delimitation of the exclusive economic zone or the continental shelf or other maritime zones, for an equitable solution to be achieved, the boundary shall be the median line, namely a line every point of which is equidistant from the nearest points of the baselines from which the breadth of the territorial waters of Malta and of such other States is measured.

Netherlands

VII. Baselines and delimitation

A claim that the drawing of baselines or the delimitation of maritime zones is in accordance with the Convention will only be acceptable if such lines and zones have been established in accordance with the Convention.

Oman:

Declaration No. 5, on the exclusive economic zone

1. The Sultanate of Oman determines that its exclusive economic zone, in accordance with article 5 of Royal Decree No. 15/81 dated 10 February 1981, extends 200 nautical miles in a seaward direction, measured from the baselines from which the territorial sea is measured.

2. The Sultanate of Oman possesses sovereign rights over its economic zone and also exercises jurisdiction over that zone as provided for in the Convention. It further declares that, in exercising its rights and performing its duties under the Convention in the exclusive economic zone, it will have due regard to the rights and duties of other States and will act in a manner compatible with the provisions of the Convention.

Declaration No. 6, on the continental shelf

The Sultanate of Oman exercises over its continental shelf sovereign rights for the purpose of exploring it and exploiting its natural resources, as permitted by geographical conditions and in accordance with this Convention.

Philippines:

8. The agreement of the Republic of the Philippines to the submission for peaceful resolution, under any of the procedures provided in the Convention, of disputes under article 298 shall not be
Keeping in view different and varied positions of various States on the Coastal States' rights to enjoy residual rights in the exclusive economic zone and taking a lesson from South China Sea disputes, author suggests that India's earlier declaration submitted at the ratification of UNCLOS on this aspect are of limited use or there is a strong need to strengthen India's position on this issue by specific exclusion of the subject from compulsory procedure of the UNCLOS. In the $59^{\text {th }}$ meeting of UNCLOS negotiations, India supported the views of Iceland, Brazil, Pakistan, Venezuela, Democratic People's Republic of Korea and Mauritius that "hard-won exclusive jurisprudence of the Coastal States in the economic zone should not be jeopardized by its submission to third-party adjudication" but India further said, it will be willing to accept mandatory settlement of disputes relating to navigation in, and overflight over, the exclusive economic zone. ${ }^{61}$ Hence, India can continue to maintain its stand on the subject of navigation in, and overflight over, the exclusive economic zone. Here it is pertinent to highlight that UK, Netherlands, Italy have made statements that in their view, the Coastal State does not enjoy residual rights in the exclusive economic zone and also went further by excluding the disputes enumerated under Article 298(1) (a) from compulsory procedure.

\subsection{Relevancy of Declarations made by States}

As discussed above, the importance of timing of submission of declaration is highly useful and of strategic importance. The author advances four propositions in this regard:

- During the continuation of declaration, a State which has a declaration regarding the optional exception clause (Article 298(1) cannot bring disputes falling within that category against any other State, even if that State has not made a similar declaration of exception (Article 298, paragraph 3)..$^{62}$

considered as a derogation of Philippines sovereignty.

61 ROSENNE, S; SOHN, L. B. United Nations Convention on the Law of the Sea 1982: A Commentary. Dordrecht: Martinuus Nijhoff Publishers, 1989. p. 93.

62 UNCLOS Article 298(3). 
- A State making such a declaration may at any time withdraw it, or agrees to submit a dispute so excluded. Thus, whenever need arises and if State (A) is interested to sue other States (B or C), a State party may agree in a particular case to submit to adjudication a dispute which is excluded from adjudication by its declaration of exemption/exclusion. This differs from general withdrawal of a declaration, as the declared exclusions remain applicable to other disputes, even those with the State with which the special agreement was concluded. ${ }^{63}$

- A new declaration or withdrawal of a declaration, does not in any way affect proceedings pending before a court or tribunal unless the parties otherwise agree. ${ }^{64}$ In other words, declaration or withdrawal has no retroactive effect on the proceedings.

- Interestingly, a State can withdraw the declaration and at the same time, can file a new declaration which is either broader or narrower.

Importantly, author summarizes that three reasons are required to be highlighted related to declarations under Article 298:

Article 299 contains two clauses in which first clause says that any dispute excluded under Article 297 or excepted under Article 298 from the dispute settlement procedures provided for in Section 2 cannot be submitted to such procedure by any party to a dispute through unilateral application. Any such action might be considered, pursuant to Article 294 of the Convention, "an abuse of legal process" or "prima facie unfounded".

The declaration made by States under Article 298 does not preclude from an agreement to submit the dispute to some other procedure outside the framework of Part XV of the UNCLOS.

Part XV is silent on the legality of declaration made under Article 298 by any forum envisaged under Article 287 so it is possible to make a comprehensive declaration of a nature which can deal with the grey areas of the UNCLOS i.e., where there is no law or there is a gap in law. This may take care of issues of sensitive matters. It should be used optimally.

As discussed in above of this study, declaration under Article 298 requires a State to exclude the subjects covered under Article 298. In brief, declaration under Article 298 is declaration of exclusion. In other wor-

63 UNCLOS Article 298(2).

64 UNCLOS Article 298(5). ds, until a declaration is made excepting some disputes, these disputes remain within the jurisdiction of the appropriate tribunal designated in accordance with Article 287 of the Convention. In this situation, absence of declaration would amount to non-exclusion of a subject from compulsory procedure. Hence, keeping in view of India's stand during the UNCLOS negotiations and India's strategies in Indian Ocean and specially Arabian Sea and its needs for development, India must ensure a comprehensive declaration under Article 298 on the sensitive matters including military activities.

\section{Conclusion}

An examination and assessment of the different forums available under Article 297 indicate that at present, ITLOS and Arbitration under Annex VII have been used extensively by States. 33 States so far expressly have chosen ITLOS and 11 States have chosen expressly Arbitration under Annex VII. However, 44 States in the Table 1 at page no. 21-22 of this study have not shown their choice of forums, i.e., by default the Arbitration under Annex VII will be the forum for settlement of law of the sea disputes for these States. It means that 44 plus 11 states (total 55 States) are of the view that Arbitration under Annex VII are their preferred mode of settlement of law of the sea disputes. (Discussed in Part I of this study) In brief, author underlines that ITLOS and Arbitration under Annex VII are most preferred forums by States. There should not be any doubt on the advantages of these forums as discussed above on any given situation.

With regard to ICJ as a preferred mode for law of the sea disputes, views are at variance and yet not being accepted as preferred mode among States. Indeed, India has already made the declaration with regard to optional jurisdiction of ICJ under Article 36(2) of the ICJ Statute and excluded various aspects of maritime disputes including maritime delimitation. Similarly, many other states have also excluded maritime disputes from ICJ jurisdiction. Hence ICJ may only remain a forum with mutual consent among parties for "application and interpretation of UNCLOS". Unless, India declares the jurisdiction of ICJ or give preference under Article 287, jurisdiction of ICJ is limited use to settle the maritime disputes. 
The author in this study finds that 51 States have not shown interest in excluding the subject (maritime delimitation) from compulsory procedure. In Europe, except France, Denmark (from Arbitration under Annex VII), Portugal, Italy, and Norway, majority of west European States have not excluded the compulsory procedure of the UNCLOS. As history suggests these five above-mentioned States have grave pains in settlement of disputes related to maritime delimitation which essentially become emotive issues. Also these States have in principle settled the issue by Court or through agreements, and they believe there is no need to re-agitate the dispute. Keeping in view the study's finding, author suggests that India should not exclude the dispute related to maritime delimitation mentioned in Article 298(1)(a) of the UNCLOS. This position of non-exclusion of maritime delimitation can also get support from the view of Dr. P. S. Rao's concurring and dissenting opinion and separate opinion in the Case of Bay of Bengal Maritime Boundary Arbitration between Bangladesh and India. ${ }^{65}$ In his view, Dr. P. S. Rao stated, "I strongly disagree both as a matter of law and policy with the creation of a "grey area" as a result of the adjustment the majority made to the provisional equidistance line, in a not insignificant expanse of the Bay of Bengal." In brief, the legality of grey area remains a juristic task which India would like to agitate this matter whenever situation will arise.” It seems Dr. P. S. Rao is well aware that due to creation of this area, India could not get economically resourceful advantages in the Bay of Bengal. Excluding the maritime delimitation from compulsory procedure of the UNCLOS may hurt India's interest in long time. However, as mentioned above in Part III, author supports the views that India may adopt another alternative approach by excluding one or two maritime areas by making declaration under Article 298 (and not all maritime areas with all of India's neighbours).

\section{References}

${ }^{1}$ FREESTONE, D. et. al. The Law of the Sea: progress and prospects. Oxford: Oxford University Press, 2006.

${ }^{2}$ KARIOTIS, T. C. (Ed.) Greece and the Law of the Sea.

$65<$ http://archive.pca-cpa.org/BD-IN\%2020140707\%20Concurring $\% 20$ and $\% 20$ Dissenting $\%$ 20Opinion $\% 20$ of $\% 20 \mathrm{Dr} \% 20$ PS\%20Rao5fb0.pdf?fil_id=2706>.
Hague: Kluwer Law International, 1997.

${ }^{3}$ NOYES, J. E. The international tribunal for the law of the sea. Cornell International Law Journal, v. 32, p. 109-182. 1999. p. 119.

${ }^{4}$ NOYES, J. E. Compulsory third party adjudication and the 1982 united nations convention on the law of the sea. Connecticut. Journal of International Law, p. 675-676, 1989. p. 678.

${ }^{5}$ CHARNEY, J. I. The implications of expanding international dispute settlement systems: the 1982 convention on the law of the sea. American Journal of International Law (AJIL), v. 90, n. 1, p. 69-75, 1996.

${ }^{6}$ KWIATKOWSKA, B. The international court of justice and the law of the sea: some reflections. The International Journal of Marine and Coastal Law (IJMCL), v. 11, n. 4, p. 491-532, 1996.

${ }^{7} \mathrm{ODA}, \mathrm{S}$. Dispute settlement prospect in the law of the sea. The International and Comparative Law Quarterly, v. 44, n. 4, p. $863-872,1995$. p. 864.

${ }^{8} \mathrm{CHARNEY}$, J. I. Progress in international maritime boundary delimitation law. American Journal of International Law, v. 88, p. 227-256, 1994. p. 228.

${ }^{9}$ In the Matter of the South China Sea Arbitration, PCA Case $\mathrm{N}^{\circ}$ 2013-19. <https://pca-cpa.org/wp-content/uploads/sites/175/2016/07/PH-CN-20160712-Award. pdf $>$.

${ }^{10}$ MERRILLS, J. G. International Dispute Settlement. $4^{\text {th }}$ ed. Cambridge: Cambridge University Press, 2005.

${ }^{11}$ BECKMAN, R. 'UNCLOS dispute settlement system' in International Conference of the South China Sea: UNCLOS and State Practice' Organized by National Institute for South China Sea Studies Haikou. October 24-25, $2013<$ http://cil.nus.edu.sg/wp/wp-content/ uploads/2014/08/Beckman-NISCSS-Hainan-Oct2013-submitted.pdf $>$.

${ }^{12}$ Position Paper of the Government of the People's Republic of China on the Matter of Jurisdiction in the South China Sea Arbitration initiated by the Republic of Philippines, 7 December 2014. < http://www.fmprc. gov.cn/mfa_eng/zxxx_662805/t1217147.shtml>.

${ }^{13}$ SUAREZ, S. V. The Outer Limits of the Continental Shelf: Legal Aspects of their Establishment. Heidelberg: Springer, 2008.

${ }^{14}$ ROSENNE, S; SOHN, L. B. United Nations Convention 
on the Law of the Sea 1982: A Commentary. Dordrecht: Martinuus Nijhoff Publishers, 1989.

${ }^{15}$ ADEDE, A. O. The System for Settlement of Disputes under the United Nations Convention on the Law of the Sea. Netherlands: Martinus Nijhoff Publishers, 1987.

${ }^{16}$ MERRILLS, J. G. International Dispute Settlement. $4^{\text {th }}$ ed. Cambridge: Cambridge University Press, 2005.

${ }^{17}$ ANDERSON, D. Modern Law of the Sea. Leiden: Martinus Nijhoff, 2008.

${ }^{18}$ COLLIER, J.; LOWE, V. The Settlement of Disputes in International Law: Institutions and Procedures. Oxford: Oxford University Press, 1999.

${ }^{19}$ KLEIN, N. Dispute Settlement in the UN Convention on the Law of the Sea. Cambridge: Cambridge University Press, 2005.
${ }^{20}$ SCHWEBEL, S. M. Ad hoc chambers of the international court of justice. AJIL, v. 81, p. 831-854, 1987.

${ }^{21}$ ROSENNE, S; SOHN, L. B. United Nations Convention on the Law of the Sea 1982: A Commentary. Dordrecht: Martinuus Nijhoff Publishers, 1989.

22 TYAGI, Yogesh K. Towards UNCLOS IV? Journal of World Trade, v. 27, Issue 1, pp. 143-154, (1993).

${ }^{23}$ CHIMNI, B. S. The new regime of oceans-illusion and reality. Indian Journal of International Law (IJIL), v. 22, 69-198, 1982.

${ }^{24}$ JAGOTA, S. P. Maritime Boundary. Dordrecht: Martinus Nijhoff Publishers, 1985.

${ }^{25}$ ANAND, R. P. Origin and Develpment of the Law of the Sea. Hague/Boston/London: Martinus Nijhoff Publishers, 1983. 
Para publicar na Revista de Direito Internacional, acesse o endereço eletrônico www.rdi.uniceub.br ou www.brazilianjournal.org.

Observe as normas de publicação, para facilitar e agilizar o trabalho de edição. 